\section{Response to: 'Glucocorticoid withdrawal in lupus: to do or not to do?' by Acharya}

We thank Acharya for her interest in our study showing that in patients with systemic lupus erythematosus (SLE) with a quiescent disease and a stable treatment regimen, for at least 1 year, withdrawal of $5 \mathrm{mg}$ of prednisone was associated with a fourfold increase (ie, 27\%), in the risk of flare onset, as defined by the SELENA-SLEDAI flare index and the British Isles Lupus Assessment Group index during a 1-year follow-up. ${ }^{12}$ Acharya states that these findings contrast with those from two previous published studies on the same subject. ${ }^{34}$ The latter studies are, however, not comparable to ours. As pointed out by Acharya, the Steroids In the Maintenance of remission of Proliferative Lupus nephritis (SIMPL) trial was a small pilot study, including only 15 patients, that was however not designed to assess the efficacy or safety of maintaining low-dose prednisone administration. ${ }^{3}$ With respect to the report of Moroni et al, in their study treatment withdrawal in patients with SLE with nephritis included not only glucocorticoids but also immunosuppressants. ${ }^{4}$ We would like to argue that the results of the CORTICOLUP trial are consistent with those of recently published observational studies, indicating that treatment with low-dose glucocorticoids prevents relapse in about one-fifth to one-third of patients with SLE with no or very low disease activity. ${ }^{56}$

As suggested by Acharya, the results might have been different had the majority of patients been on immunosuppressant therapy. We, of course, do acknowledge that the results of the CORTICOLUP study cannot be extrapolated to all patients in remission. The percentage of patients treated with an immunosuppressant in the CORTICOLUP study, amounting to $27 \%$, reflects the clinical practice of our team. Moreover, our practice is comparable to that of other teams. ${ }^{57}$ Yet, the indication of an immunosuppressive treatment is not evidence based, especially in patients in remission, and depends to date on the decision of the physician and therefore varies according to his/her convictions. Finally, in the interaction analysis shown in figure 3 in our study, ${ }^{2}$ there was no significant interaction between the effect of prednisone maintenance and immunosuppressants or hydroxychloroquine.

To conclude, like Acharya, we believe that prescribing an immunosuppressant or a biologic might reduce the use of prolonged glucocorticoid therapy to prevent relapse of the disease. However, this belief has to be proved and balanced with the infectious and oncological risk possibly brought about by long-term exposure to this type of medication.

\section{Alexis Mathian $\odot$, Micheline Pha, Zahir Amoura}

Sorbonne Université, Assistance Publique-Hôpitaux de Paris, Groupement Hospitalier Pitié-Salpêtrière, French National Referral Center for Systemic Lupus Erythematosus,
Antiphospholipid Antibody Syndrome and Other Autoimmune Disorders, Service de Médecine Interne 2, Institut E3M, Inserm UMRS, Centre d'Immunologie et des Maladies Infectieuses (CIMI-Paris), Paris, France, Paris, France

Correspondence to Pr Zahir Amoura, Internal Medicine, Pitié Salpétrière, Paris 75651, France; zahir.amoura@aphp.fr

Handling editor Josef S Smolen

Contributors AM, MP and ZA contributed to drafting and revising the manuscript.

Funding The authors have not declared a specific grant for this research from any funding agency in the public, commercial or not-for-profit sectors.

Competing interests None declared.

Patient and public involvement Patients and/or the public were not involved in the design, or conduct, or reporting, or dissemination plans of this research.

Patient consent for publication Not required.

Provenance and peer review Commissioned; internally peer reviewed.

(c) Author(s) (or their employer(s)) 2020. No commercial re-use. See rights and permissions. Published by BMJ.

\section{Check for updates}

To cite Mathian A, Pha M, Amoura Z. Ann Rheum Dis Epub ahead of print: [please include Day Month Year]. doi:10.1136/annrheumdis-2020-217282

Received 14 March 2020

Accepted 17 March 2020

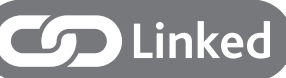

http://dx.doi.org/10.1136/annrheumdis-2020-217261

Ann Rheum Dis 2020;0:1. doi:10.1136/annrheumdis-2020-217282

ORCID iD

Alexis Mathian http://orcid.org/0000-0002-7653-6528

\section{REFERENCES}

1 Acharya N. Glucocorticoid withdrawal in lupus - to do or not to do? Ann Rheum Dis 2020. doi:10.1136/annrheumdis-2020-217261. [Epub ahead of print: 10 Mar 2020].

2 Mathian A, Pha M, Haroche J, et al. Withdrawal of low-dose prednisone in SLE patients with a clinically quiescent disease for more than 1 year: a randomised clinical trial. Ann Rheum Dis 2020;79:339-46.

3 Galbraith L, Manns B, Hemmelgarn B, et al. The steroids in the maintenance of remission of proliferative lupus nephritis (SIMPL) pilot trial. Can J Kidney Health Dis 2014; 1:30.

4 Moroni G, Gallelli B, Quaglini S, et al. Withdrawal of therapy in patients with proliferative lupus nephritis: long-term follow-up. Nephrol Dial Transplant 2006;21:1541-8.

5 Tani C, Elefante E, Signorini V, et al. Glucocorticoid withdrawal in systemic lupus erythematosus: are remission and low disease activity reliable starting points for stopping treatment? A real-life experience. RMD Open 2019;5:e000916.

6 Goswami RP, Sit H, Ghosh P, et al. Steroid-Free remission in lupus: myth or reality; an observational study from a tertiary referral centre. Clin Rheumatol 2019;38:1089-97.

7 Cervera R, Khamashta MA, Font J, et al. Morbidity and mortality in systemic lupus erythematosus during a 10-year period: a comparison of early and late manifestations in a cohort of 1,000 patients. Medicine 2003;82:299-308. 